\title{
Effect of p53 Overexpression on Radiation Sensitivity of Human Colon Cancer Cells
}

\author{
Richard C. Zellars, M.D., John D. Naida, M.D., Mary A. Davis, Ph.D., and \\ Theodore S. Lawrence, M.D., Ph.D.* \\ Department of Radiation Oncology, The University of Michigan, Ann Arbor, Michigan
}

\begin{abstract}
SUMMARY Substantial controversy surrounds our understanding of the effect of p53 status on radiation sensitivity. To assess directly the role of p53 expression on radiation sensitivity, we chose a conditional expression system using a temperature-sensitive murine p53 that permitted each cell line to act as its own control. We found that the conditional expression of wild type p53 induced cell death (both apoptotic and nonapoptotic), changes in cell cycle distribution (arrest in $G_{1}$ and $G_{2}$, which resulted in a marked depletion of $S$-phase cells and an increase in the fraction of cells in $G_{2}$ ), and an increase in the radiation resistance of $G_{1}$ cells. These counterbalancing effects resulted in no significant effect on overall radiosensitivity. These findings demonstrate that wild type p53 function can produce a variety of effects that can modulate radiation sensitivity and may explain why p53 status alone has not been a strong predictor of radiosensitivity. Radiat. Oncol. Invest. 5:43-49, 1997. ㄷ 1997 Wiley-Liss, Inc.
\end{abstract}

Key words: p53; apoptosis; cell cycle; radiation sensitivity

\section{INTRODUCTION}

The effect of p53 status on radiation sensitivity is controversial. For instance, in a transplantable fibrosarcoma model using tumors that differed only with respect to functional p53 status, p53 minus tumors were more radioresistant than their wild type (wt) p53 counterparts [1]. Conversely, others have reported finding no correlation between $\mathrm{p} 53$ status and radiosensitivity [2-4]. There are a number of possible reasons for these conflicting results. Probably the most important is that the expression of wt p53, in its multiple roles as transcription factor and participant in the recognition of DNA damage, can produce several effects that could influence radiation sensitivity during a fractionated course of radiation, namely, 1) cytotoxicity, 2) cell cycle redistribution, and 3 ) arrest at the $G_{1} / S$ boundary. Another reason for controversy is that some investigators have compared cells with wt p53 to those with mutant p53 [5-7], whereas others have made comparisons to E6 deleted or p53 null cells $[8,9]$. An additional reason for disparate results is methodological. Previous studies have used different cells lines or the individual clones selected from a mixed population, both of which can evidence wide variability in radiation sensitivity [10]. Thus, it has been difficult to determine whether an observed difference in radiation sensitivity is due to alteration in p53 status or to random variation resulting from other clonal differences.

We wished to design a study of the potential role of p53 in radiation sensitivity that addressed these potential confounding factors. We chose a conditional expression system using a temperature sensitive murine p53, which permitted each cell line to act as its own control, thus removing the issue of clonal variability within a given experiment. We found that elevation of functional p53 caused cell death, cell cycle redistribution $\left(\mathrm{G}_{1}\right.$ and $\mathrm{G}_{2}$ arrest, resulting in $\mathrm{S}$-phase depletion), a de-

Contract grant sponsor: NIH; Contract grant number: CA53440; Contract grant sponsor: Cancer Center Core; Contract grant number: CA46592.

*Correspondence to: Theodore S. Lawrence, M.D., Ph.D., Division of Radiation and Cancer Biology, Department of Radiation Oncology, The University of Michigan, 1331 E. Ann Street, Ann Arbor, MI 48109-0582. E-mail: tsl@umich.edu

Received 26 September 1996; Revised 13 March 1997; Accepted 3 April 1997

(C) 1997 Wiley-Liss, Inc. 
crease in sensitivity of the $G_{1}$ fraction, but no overall change in radiation sensitivity. These changes suggest that, although p53 status has profound effects on the cell, a knowledge of p53 status alone will not permit the prediction of radiation sensitivity.

\section{MATERIALS AND METHODS}

\section{Cell Lines}

We used HT29 human colon cancer cells, which contain mutant p53 (His 273). Cells were transfected with a temperature-sensitive mutant p53 gene (p53 val-135) [11,12] and are described elsewhere [13]. In brief, cells were transduced by electroporation (in the laboratory of Michael Clarke, University of Michigan) using a transfection mixture of $10^{7}$ cells in phosphate-buffered saline (PBS) with $4 \mu \mathrm{g}$ of linearized plasmid DNA, and cells were then selected by G418 (Life Technologies, Grand Island, NY). At the permissive temperature of $32^{\circ} \mathrm{C}$, the p53 protein assumes a conformation that permits translocation to the nucleus and wild type function. At $38^{\circ} \mathrm{C}$, p53 is concentrated in the cytoplasm and is therefore nonfunctional [11]. Two resulting cell lines were chosen, called ts29-A and ts29-G, both of which overexpress p53 [13]. A control cell line, HT29neo, was also constructed by infection with an amphitropic retrovirus made by inserting the neomycin resistance gene into pLNSX. The presence of the murine p53 gene product in transduced ts 29 cells was confirmed by Northern and Western analysis (not shown). The cell lines ts29-A, ts29-G, and HT29neo were cultured under standard conditions by using RPMI medium supplemented with $10 \%$ calf serum and $800 \mu \mathrm{g} / \mathrm{ml}$ of G418. Cells were released from the flasks with PBS with $0.03 \%$ trypsin and $0.27 \mathrm{mM}$ EDTA.

\section{Clonogenic Assay}

Cell survival was assessed by using a standard clonogenic survival assay, as previously described [14]. Radiation survival data were corrected for plating efficiency by using unirradiated plates grown under the same conditions as the irradiated cells. Cell survival curves were fitted by using a linear quadratic equation, and the mean inactivation dose, which represents the area under the cell survival curve, was calculated according to the method of Fertil and colleagues [15]. Cells were returned to the nonpermissive temperature immediately following replating at clonal density, regardless of whether they were incubated at the permissive temperature before or after irradiation.

\section{Irradiation Technique}

Cells were irradiated using ${ }^{60} \mathrm{Co}$ at $1-2 \mathrm{~Gy} / \mathrm{min}$. Dosimetry was carried out by using an ionization chamber connected to an electrometer system that was directly traceable to a NIST standard.

\section{Flow Cytometry}

Cells were trypsinized, washed in PBS, fixed by drop-wise addition of 2.5 volumes of cold $70 \%$ ethanol, and stored at $4^{\circ} \mathrm{C}$ until the day of analysis. They were then washed with PBS, suspended in propidium iodide, and analyzed on an EPICS C flow cytometer (Coulter Electronics, Hialeah, FL). Human leukocytes were used as an internal standard. Cell cycle phase distribution was estimated with CytoLogic software, based on a multiple broadened rectangular S-phase model. For twoparameter flow cytometry, cells were processed for the immunoassay with the first antibody (mouse antibromodeoxyuridine; anti-BrdUrd; PharMingen, San Diego, CA) followed by FITC-goat-antimouse IgG (Sigma, St. Louis, MO) [16].

\section{Assessment of Apoptosis}

Cells were trypsinized and washed once with PBS. They were then fixed by incubation in $4 \%$ paraformaldehyde at a concentration of $10^{6}$ cells $/ \mathrm{ml}$ for $30 \mathrm{~min}$ at room temperature and then washed again with PBS. The fixed cells were resuspended in PBS at a concentration of $10^{4}$ cell $/ \mathrm{ml}$. Thirty-five milliliters of the cell suspension were mixed with $5 \mathrm{ml}$ of $100 \mathrm{mg} / \mathrm{ml}$ acridine orange solution and $10 \mathrm{ml}$ Vectashield (Vector Laboratories, Burlingame, CA). The mixture was examined by using a Leitz Laborlux S microscope equipped with a 1-Lambda Pleomopak incident light fluorescence illuminator (450-490 nm excitation wavelength with $520 \mathrm{~nm}$ barrier filter). Cells were scored as apoptotic if they exhibited both chromatin condensation and nuclear shrinkage.

\section{Statistical Analysis}

Unless otherwise indicated, all data are presented as the mean \pm standard error of at least three experiments. Student's t test was used to compare two means. Multiple means were compared by using the $F$ test. Statistical significance was defined at the level of $P<0.05$ (two-tailed). For all of the figures, the results of a single representative experiment are shown. Clonogenicity was measured in triplicate within each experiment. Unless shown, error bars are contained within the size of the symbol. 
Table 1. Effect of Induction of Wild Type p53 Function on Cell Cycle Distribution

\begin{tabular}{|c|c|c|c|c|c|c|}
\hline \multirow[b]{3}{*}{ Phase (\%) } & \multicolumn{6}{|c|}{ Cell line } \\
\hline & \multicolumn{2}{|c|}{ HT29neo } & \multicolumn{2}{|c|}{ ts $29-A$} & \multicolumn{2}{|c|}{ ts $29-\mathrm{G}$} \\
\hline & $38^{\circ}$ & $32^{\circ \mathrm{a}}$ & $38^{\circ}$ & $32^{\circ \mathrm{a}}$ & $38^{\circ}$ & $32^{\circ a}$ \\
\hline $\mathrm{G}_{0}-\mathrm{G}_{1}$ & $53 \pm 4$ & $50 \pm 1$ & $54 \pm 2$ & $54 \pm 3$ & $61 \pm 2$ & $58 \pm 3$ \\
\hline S & $26 \pm 4$ & $31 \pm 2$ & $27 \pm 3$ & $11 \pm 2^{\mathrm{b}}$ & $23 \pm 3$ & $10 \pm 2^{\mathrm{b}}$ \\
\hline $\mathrm{G}_{2}-\mathrm{M}$ & $20 \pm 1$ & $21 \pm 2$ & $19 \pm 2$ & $35 \pm 4^{\mathrm{b}}$ & $16 \pm 2$ & $33 \pm 3^{\mathrm{b}}$ \\
\hline
\end{tabular}

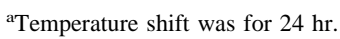

${ }^{\mathrm{b}}$ Differs from $38^{\circ}(P<0.05)$.

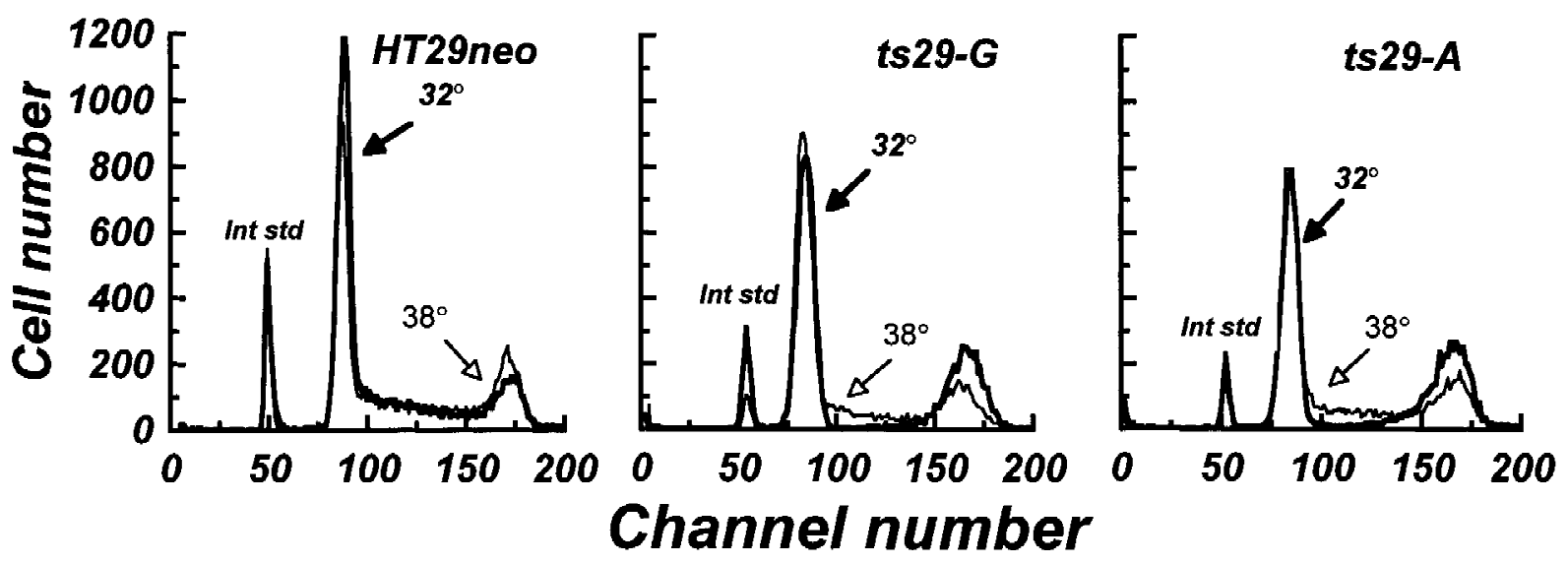

Fig. 1. Effect of p53 status on cell cycle distribution. Cells from the ts29-A and ts29-G cell lines were incubated at permissive $\left(32^{\circ} \mathrm{C}\right)$ and nonpermissive $\left(38^{\circ} \mathrm{C}\right)$ temperatures for $24 \mathrm{hr}$, and cell cycle distribution was assessed by flow cytometry. The results of one of three similar experiments are shown.

\section{RESULTS}

We had hypothesized that expression of wt p53 function might induce apoptosis. We first examined whether the cells that detached from the dish were apoptotic [17]. For these experiments, we shifted ts $29-\mathrm{G}$ cells to $32^{\circ} \mathrm{C}$ for $48 \mathrm{hr}$ and examined them at varying times $(0,2,4,8,24$, and $72 \mathrm{hr})$ after returning them to $38^{\circ} \mathrm{C}$. At the end of the $48-\mathrm{hr}$ exposure (time 0 ), the fraction of cells that was nonadherent was $1 \%$. Cells remaining adherent to the dish did not show nuclear changes. In contrast, we found that the great majority $(>90 \%)$ of the floating cells showed evidence of fragmented nuclei. We found that $10-15 \%$ of the cells were not adherent $72 \mathrm{hr}$ after the completion of a 48-hr shift to the permissive temperature. However, we also found that a 48-hr shift to the permissive temperature reduced the clonogenic survival of ts $29-\mathrm{G}$ and ts 29 -A cells to $0.32 \pm 0.07$ and $0.58 \pm 0.05$, respectively. Therefore, even if we assume that all nonadherent cells died by apoptosis, the apoptotic fraction was less than the loss of clonogenicity produced under the same conditions. Neither apoptosis nor a decrease in clonogenic survival $(1.20 \pm 0.15)$ were observed in HT29neo cells after exposure to the permissive temperature for $48 \mathrm{hr}$.

Because we had hypothesized that changes in cell cycle distribution could occur from wt p53 expression, we examined the cell cycle distribution of both our control and study cell populations. Cells from the ts29-A, ts29-G, and HT29neo cell lines that were grown at the nonpermissive temperature showed a flow cytogram pattern similar to the one we have reported previously for parental HT29 cells [18]. At the permissive temperature of $32^{\circ} \mathrm{C}$, ts29-A and ts29-G cells evidenced a significant depletion of cells in S-phase and a significant increase in the fraction of cells in $\mathrm{G}_{2} / \mathrm{M}$-phase. In contrast, HT29neo cells grown at the permissive temperature showed no significant change in the fraction of cells in $G_{2} / M$ (Table 1, Fig. 1).

To assess definitively the effect of wt p53 function on cell cycle progression, we cultured cells at the permissive temperature for $48 \mathrm{hr}$ and labeled S-phase ts29-G cells and HT29neo cells by using BrdUrd (30 $\mu \mathrm{M}$ for 15 min; Fig. 2). HT29neo 

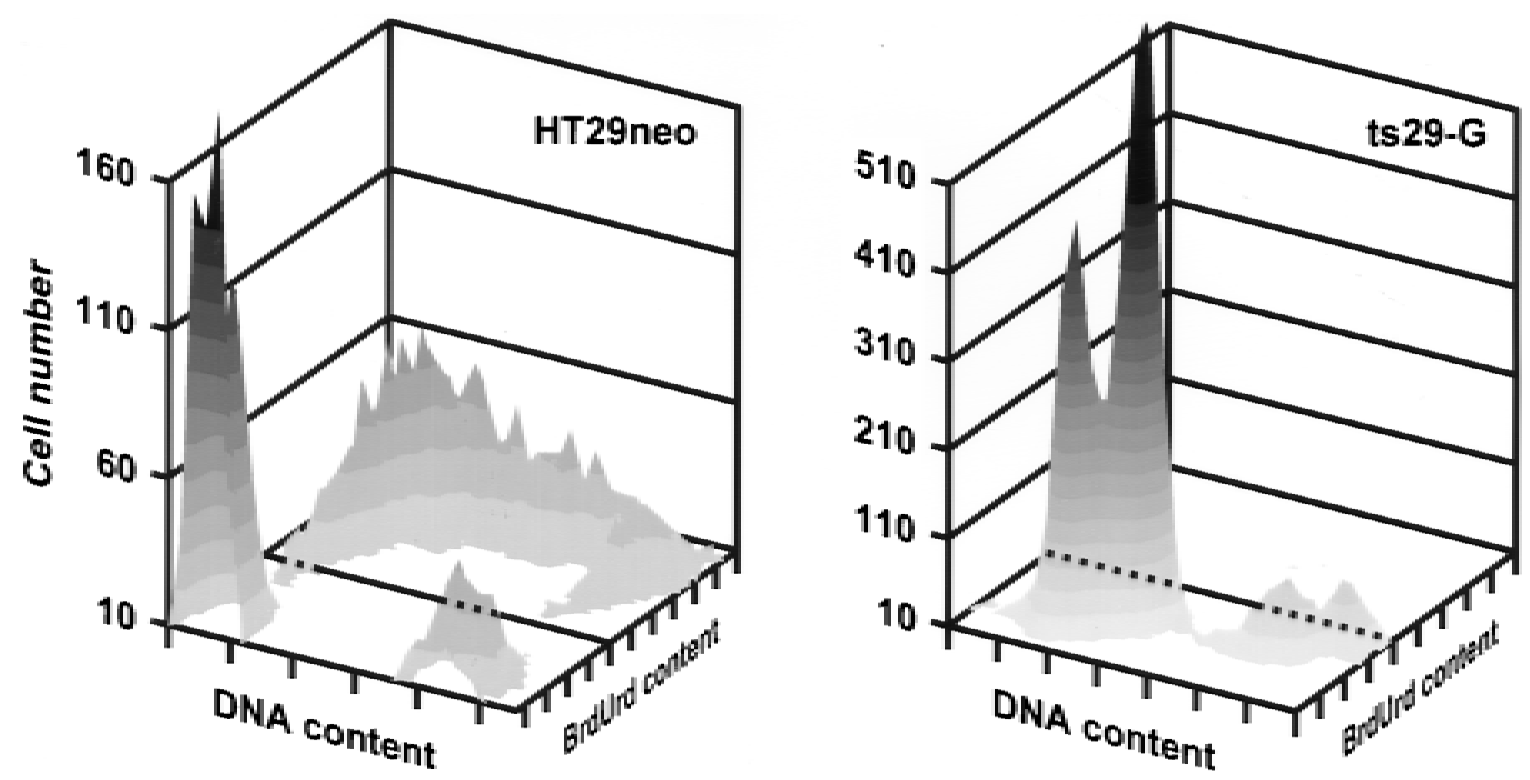

Fig. 2. Effect of p53 status on cell cycle progression. HT29neo and ts $29-\mathrm{G}$ cells were incubated at the permissive $\left(32^{\circ} \mathrm{C}\right)$ temperature for $48 \mathrm{hr}$ and then exposed to bromodeoxyuridine (BrdUrd; $30 \mu \mathrm{M}$ for $15 \mathrm{~min}$ ) prior to processing. Cells were processed for two-parameter flow cytometry, as described in Materials and Methods. Darker line separates BrdUrd ${ }^{+}$and $\mathrm{BrdUrd}^{-}$cells (based on control samples). BrdUrd content is expressed in log units of green fluorescence. The results of one of three similar experiments are shown.
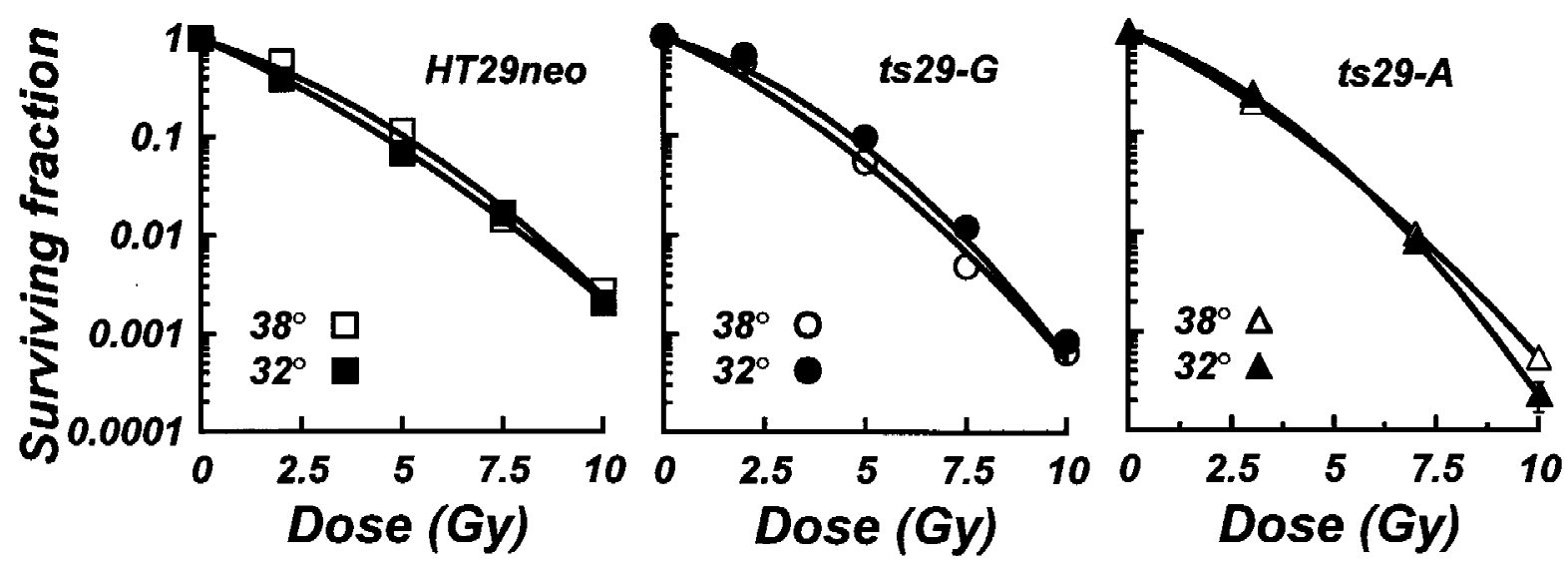

Fig. 3. Effect of p53 status on radiation sensitivity. HT29neo, ts $29-\mathrm{A}$, and ts $29-\mathrm{G}$ cells were incubated at permissive $\left(32^{\circ} \mathrm{C}\right)$ and nonpermissive $\left(38^{\circ} \mathrm{C}\right)$ temperatures for $48 \mathrm{hr}$ immediately prior to irradiation. Survival was measured by clonogenic assay. The results of one of three similar experiments are shown.

cells treated at $32^{\circ} \mathrm{C}$ showed a standard twoparameter flow pattern for untreated cells. However, at $32^{\circ} \mathrm{C}$, ts $29-\mathrm{G}$ cells showed no BrdUrd incorporation. This confirms the results of the oneparameter flow experiments, demonstrating that $\mathrm{wt}$ p53 function produces $G_{1}$ and $G_{2}$ arrest leading to S-phase depletion.

We then wished to determine how the expression of wt p53 function would affect radiation sensitivity. For these experiments, ts29-A, ts29-G, and HT29neo cells were incubated for 24 or $48 \mathrm{hr}$ under permissive and nonpermissive conditions after or prior to irradiation. However, none of these three cell lines exhibited a difference in radiation sensitivity as a function of permissive vs. nonpermissive temperature (Fig. 3, Table 2). We found this result surprising for the ts29-A and ts29-G cells, which had been shifted to the permissive temperature prior to irradiation. Because $\mathrm{S}$-phase, in general, is radioresistant $[19,20]$, we had anticipated that a depletion in this phase of the cell cycle would produce radiosensitivity. It seemed likely, therefore, 
Table 2. Effect of Induction of Wild Type p53 Function on Radiation Sensitivity

\begin{tabular}{lccccc}
\hline & \multicolumn{5}{c}{ Mean inactivation dose $(\mathrm{Gy})$} \\
\cline { 2 - 6 } Cell type & $38^{\circ} \mathrm{C}$ & $\begin{array}{c}32^{\circ} \mathrm{C} 24 \mathrm{hr} \\
\text { prior to XRT }\end{array}$ & $\begin{array}{c}32^{\circ} \mathrm{C} 24 \mathrm{hr} \\
\text { post-XRT }\end{array}$ & $\begin{array}{c}32^{\circ} \mathrm{C} 48 \mathrm{hr} \\
\text { prior to XRT }\end{array}$ & $\begin{array}{c}32^{\circ} \mathrm{C} 48 \mathrm{hr} \\
\text { post-XRT }\end{array}$ \\
\hline HT29neo & $2.5 \pm 0.1$ & $2.6 \pm 0.1$ & $2.5 \pm 0.1$ & $2.3 \pm 0.2$ & $2.8 \pm 0.1$ \\
ts29-A & $2.0 \pm 0.1$ & $2.1 \pm 0.1$ & $1.7 \pm 0.1$ & $2.3 \pm 0.1$ & $2.1 \pm 0.1$ \\
ts29-G & $2.1 \pm 0.1$ & $1.7 \pm 0.1$ & $1.5 \pm 0.1$ & $2.3 \pm 0.1$ & $2.0 \pm 0.1$ \\
\hline
\end{tabular}

that either the $G_{1}$ arrested population or the $G_{2} / M$ arrested population (or both) had become more radioresistant. To test this hypothesis, we grew ts $29-\mathrm{G}$ cells at $32^{\circ} \mathrm{C}$ or $38^{\circ} \mathrm{C}$ for $48 \mathrm{hr}$, flow sorted the $G_{1}$ cells and the $G_{2} / M$ cells, and assessed the different populations for radiosensitivity. We found that $\mathrm{G}_{1}$ cells grown at $32^{\circ} \mathrm{C}$ were significantly more radioresistant than those grown at $38^{\circ} \mathrm{C}$ (Fig. 4). The MID dose in the temperature-shifted cells increased from $2.1 \pm 0.1$ Gy to $2.9 \pm 0.1 \mathrm{~Gy}$. A similar trend was observed with the $\mathrm{G}_{2} / \mathrm{M}$ cells, in that the MID dose increased from a $2.2 \pm 0.1$ Gy to $2.5 \pm 0.1 \mathrm{~Gy}$ in temperature-shifted cells, although this difference did not reach statistical significance.

We then hypothesized that the $G_{1}$ population of p53-expressing cells grown at the permissive temperature were radioresistant because they had a prolonged arrest in $G_{1}$ even after being returned to the nonpermissive temperature. We found that both ts $29-G$ and ts $29-A$ cells remained in $G_{1}$ for $6 \mathrm{hr}$ after being returned to the nonpermissive temperature; progression was detectable at $12 \mathrm{hr}$ after the shift to $38^{\circ} \mathrm{C}$ (Fig. 5). This shows that transient expression of wt p53 function produces transient $\mathrm{G}_{1}$ arrest in these cells.

\section{DISCUSSION}

We have shown that the conditional expression of wt p53 function using a murine temperaturesensitive mutant does not affect overall radiation sensitivity of HT29 human colon cancer cells. This is true regardless of whether cells are placed at the permissive temperature immediately after radiation or for $24-48 \mathrm{hr}$ prior to irradiation. However, the expression of wt p53 function in these cells does produce profound effects, including apoptosis, decreased clonogenicity, $\mathrm{G}_{1}$ and $\mathrm{G}_{2} / \mathrm{M}$ arrest (with a resulting $S$-phase depletion), and radiation resistance of the $G_{1}$ fraction. These findings suggest that it is unlikely that p53 status alone will affect radiation sensitivity in the same fashion for all cells. Rather, the overall radiation sensitivity of a cell type will be determined by a complex interrelationship among p53-dependent (and p53-independent)

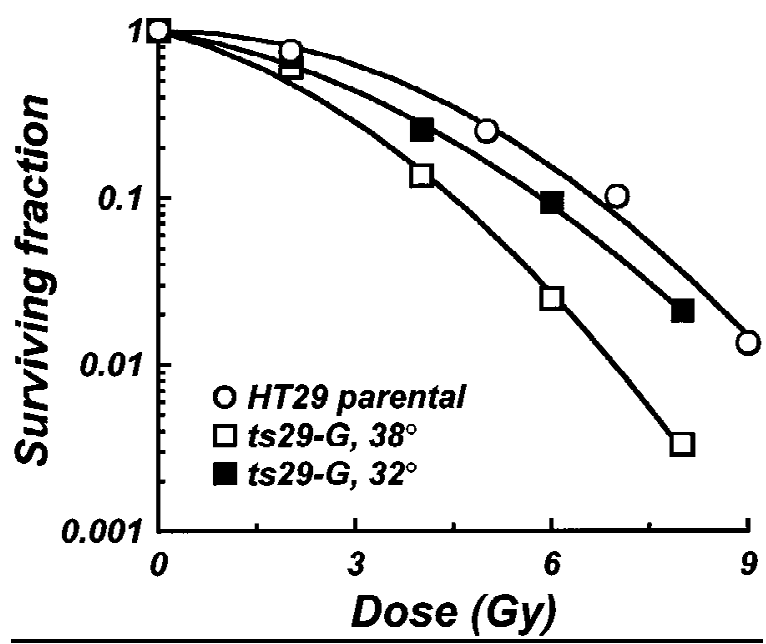

Fig. 4. Effect of p53 status on radiation sensitivity of $\mathrm{G}_{1}$ cells. Control (HT29) and ts29-G cells were incubated at permissive $\left(32^{\circ} \mathrm{C}\right)$ and nonpermissive $\left(38^{\circ} \mathrm{C}\right)$ temperatures for $48 \mathrm{hr}$ immediately prior to flow sorting. $\mathrm{G}_{1}$-phase cells were irradiated and assessed for survival by a clonogenic assay. The results of one of three similar experiments are shown.

effects, which will probably be cell type- and tissue type-dependent.

Our finding that conditional expression of p53 produces apoptosis is consistent with that of a number of investigators [21,22]. Hartwell and Kastan have hypothesized that there is a biologically significant level of spontaneous DNA damage that requires checkpoint control in order for cells to maintain a high fidelity of chromosome transmission [23]. It is consistent with this model that HT29 cells, which have a highly abnormal karyotype [18], would undergo apoptosis as a result of wt p53 expression. However, apoptosis accounts for only a fraction of the of the loss of clonogenicity, so its importance in this system remains unclear.

We are unaware of other investigations evaluating the radiosensitivity of $G_{1}$ cells arrested due to elevations of p53 levels. However, it is well known that cells arrested in $G_{1} / G_{0}$ from liquid holding or from contact inhibition (plateau phase) evidence decreased radiation sensitivity due to potentially 


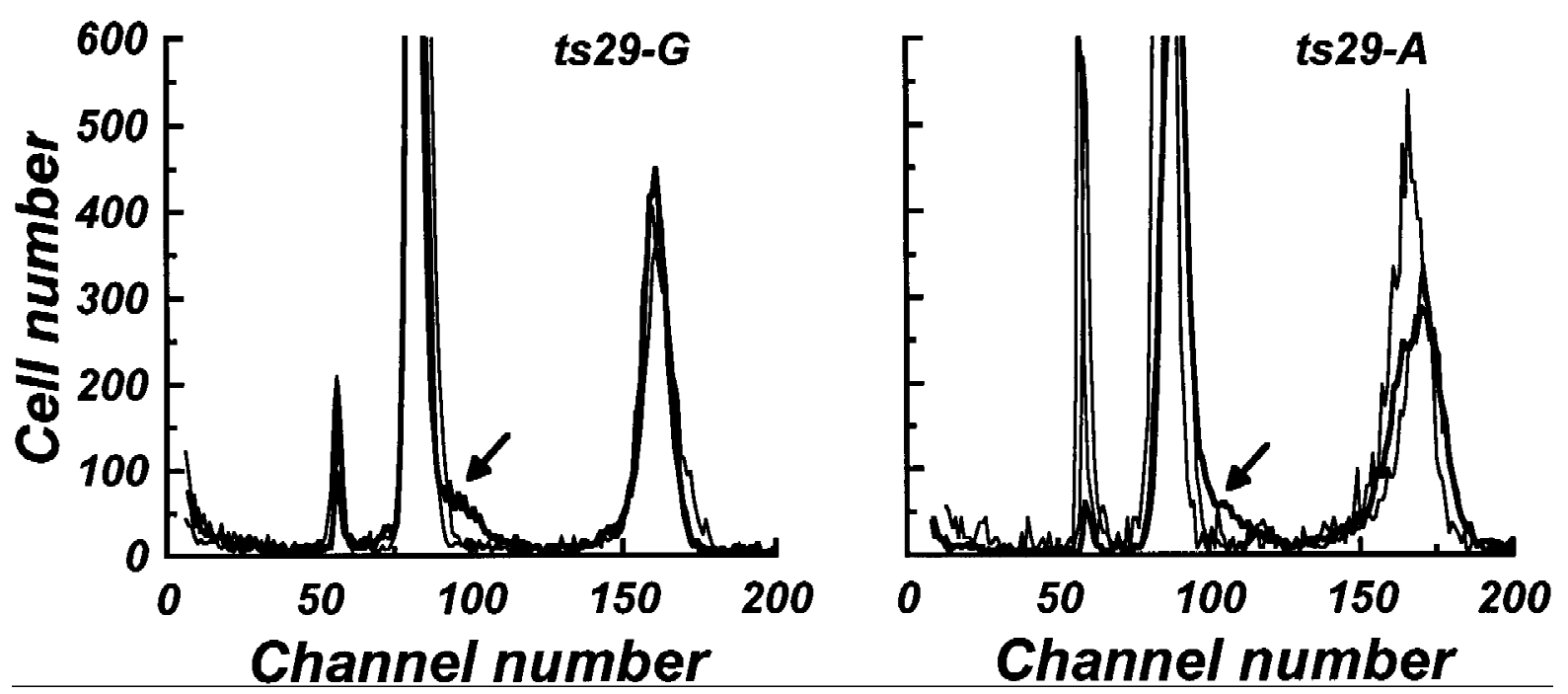

Fig. 5. Duration of effect of temperature shift on cell cycle distribution. Cells from the ts $29-\mathrm{G}$ cell line were incubated at the permissive $\left(32^{\circ} \mathrm{C}\right)$ temperature for $48 \mathrm{hr}$. They were then returned to the non permissive temperature $\left(38^{\circ} \mathrm{C}\right)$ and assessed by flow cytometry immediately $(0 \mathrm{hr}), 6 \mathrm{hr}$, and $12 \mathrm{hr}$ later. The $0 \mathrm{hr}$ and $6 \mathrm{hr}$ cytograms are superimposed. The arrow indicates early S-phase cells in the cells shifted for $12 \mathrm{hr}$.

lethal damage repair (PLDR). Perhaps our findings may be viewed as another form of PLDR in which cells are permitted to repair DNA damage before progressing into S-phase. The influence of p53 function on the radiation sensitivity of cells in $G_{1}$ has been assessed by using U-87 glioblastoma cells (which demonstrate wt p53 function) and a transfected derivative in which $\mathrm{p} 53$ had been inactivated [24]. In this study, p53 mutant cells synchronized in $G_{1}$ were more resistant than the wild type parental $\mathrm{G}_{1}$ cells. Although this appears at first to contrast with our results, the mechanism of increased sensitivity of the wild type parental appeared to be related to an irreversible $G_{1}$ arrest. In our study, cells were returned to the nonpermissive temperature after irradiation and left $\mathrm{G}_{1}$ 12-24 hr later (see Fig. 5). Thus, it seems possible, based on both studies, that transient p53 expression and $G_{1}$ arrest may confer protection (present study), whereas permanent p53 expression and $G_{1}$ arrest may represent an important form of loss of clonogenicity [24].

There are a number of limitations to this study. Our conditional expression required placing cells at a lower temperature, which could affect other cellular functions. However, our control HT29neo cells showed minimal changes in radiation sensitivity and cell cycle distribution at $32^{\circ} \mathrm{C}$ compared with $38^{\circ} \mathrm{C}$, so it is unlikely that temperature alone had a major impact on our results. In addition, the parental HT29 cells used in this study express mutant $\mathrm{p} 53$, so that, at the permissive temperature, we are observing the combination of a murine wt and a human mutant p53. However, at the permissive temperature, these cells demonstrate $\mathrm{p} 21$ activation [13] (Naida et al., submitted), $G_{1}$ cell cycle arrest, and $G_{2} / M$ arrest, which strongly suggest that the murine p53 is functional despite the presence of the endogenous mutant p53 [25-28]. Finally, although we have focused on a number of p53-mediated effects in attempting to understand radiosensitivity changes, it is possible that there are additional factors we have not considered. For instance, the bcl-2 $[29,30]$ or bcl- $x_{L}$ [13] levels could change in response to changes in $\mathrm{p} 53$ function produced by the permissive temperature, which could then affect cell death. However, this point serves to emphasize the complexity of the relationship between p53 status and radiation sensitivity.

\section{ACKNOWLEDGMENTS}

We thank Jonathan Maybaum and Sande Merchant for access to unpublished data and Marlene Langley for secretarial assistance. This work was supported by NIH grant CA53440, Cancer Center Core grant CA46592, and an ASTRO fellowship (R.C.Z.).

\section{REFERENCES}

1. Lowe SW, Bodis S, McClatchey A, Remington L, Ruley HE, Fisher DE, Housman DE, Jacks T: P53 status and the efficacy of cancer therapy in vivo. Science 266:807-810, 1994.

2. Brachman DG, Beckett M, Graves D, Haraf D, Yokes E, Weichelsbaum R: p53 Mutation does not correlate 
with radiosensitivity in 24 head and neck cancer cell lines. Cancer Res 53:3667-3669, 1993.

3. Jung M, Notario V, Dritschilo A: Mutations in the p53 gene in radiation-sensitive and -resistant human squamous carcinoma cells. Cancer Res 52:6390-6393, 1992.

4. Slichenmyer WJ, Nelson WG, Slebos RJ, Kastan MB: Loss of p53-associated $G_{1}$ checkpoint does not decrease cell survival following DNA damage. Cancer Res 53:164-168, 1993.

5. Servomaa K, Kiuru A, Grenman R, Pekkola-Heino K, Pulkkinen JO, Rytomaa T: p53 Mutations associated with increased sensitivity to ionizing radiation in human head and neck cancer cell lines. Cell Prolif 29(5): 219-230, 1996.

6. Gjerset RA, Turla ST, Sobol RE, Scalise JJ, Mercola D, Collins H, Hopkins PJ: Use of wild-type p53 to achieve complete treatment sensitization of tumor cells expressing endogenous mutant p53. Mol Carcinogenesis 14(4): 275-285, 1995.

7. Fan S, el Deiry WS, Bae I, Freeman J, Jondle D, Bhatia K, Fornace AJ Jr, Magrath I, Kohn KW, O'Connor PM: p53 Gene mutations are associated with decreased sensitivity of human lymphoma cells to DNA damaging agents. Cancer Res 54(22):5824-5830, 1994.

8. Huang H, Li CY, Little JB: Abrogation of p53 function by transfection of 2HPV16 E6 gene does not enhance resistance of human tumour cells to ionizing radiation. Int J Radiat Biol 70(2):151-160, 1996.

9. Tsang NM, Nagasawa H, Li C, Little JB: Abrogation of p53 function by transfection of HPV16 E6 gene enhances the resistance of human diploid fibroblasts to ionizing radiation. Oncogene 10(12):2403-2408, 1995.

10. Kasid UN, Weichselbaum RR, Brennan T, Mark GE, Dritschilo A: Sensitivities of NIH/3T3-derived clonal cell lines to ionizing radiation: Significance for gene transfer studies. Cancer Res 49:3396-3400, 1989.

11. Ginsberg D, Michael-Michalovitz D, Ginsberg D, Oren M: Induction of growth arrest by a temperaturesensitive p53 mutant is correlated with increased nuclear localization and decreased stability of the protein. Mol Cell Biol 11:582-585, 1991.

12. Michalovitz D, Halvey O, Orens M: Conditional inhibition of transformation and of cell proliferation by a temperature-sensitive mutant of p53. Cell 62:671-680, 1990.

13. Merchant AK, Loney TL, Maybaum J: Expression of wild-type p53 stimulates an increase in both Bax and $\mathrm{Bcl}-\mathrm{x}_{\mathrm{L}}$ protein content in HT29 cells. Oncogene 13:2631-2637, 1996.

14. Lawrence TS, Davis MA, Maybaum J, Mukhopadhay SK, Stetson PL, Normolle DP, McKeever PE, Ensminger WD: The potential superiority of bromodeoxyuridine to iododeoxyuridine as a radiation sensitizer in the treatment of colorectal cancer. Cancer Res 52: 3698-3704, 1992.

15. Fertil B, Dertinger H, Courdi A, Malaise EP: Mean inactivation dose: A useful concept for intercomparison of human cell survival curves. Radiat Res 99:73-84, 1984.
16. Hoy CA, Seamer LC, Schimke RT: Thermal denaturation of DNA for immunochemical staining of incorporated bromodeoxyuridine (BrdUrd): Critical factors that affect the amount of fluorescence and the shape of BrdUrd/DNA histogram. Cytometry 10:718-725, 1989.

17. Childs S, Yeh RL, Georges E, Ling V: Identification of a sister gene to P-glycoprotein. Cancer Res 55:20292034, 1995.

18. Wilt SR, Burgess AC, Normolle DP, Trent JM, Lawrence TS: Use of fluorescence in situ hybridization (FISH) to study chromosomal damage induced by radiation and bromodeoxyuridine in human colon cancer cells. Int J Radiat Oncol Biol Phys 30:861-866, 1994.

19. Terasima T, Tolmach LJ: Variations in several responses of HeLa cells to x-irradiation during the division cycle. Biophysics J 3:11-33, 1963.

20. Sinclair WK: Cyclic x-ray responses in mammalian cells in vitro. Radiat Res 33:620-643, 1968.

21. Lowe SW, Schmitt EM, Smith SW, Osborne BA, Jacks $\mathrm{T}: \mathrm{p} 53$ is required for radiation-induced apoptosis in mouse thymocytes. Nature 362:847-849, 1993.

22. Yonish-Rouach E, Resnitzky D, Lotem J, Sach L, Kimichi A, Oren M: Wild type p53 induced apoptosis of myeloid leukemic cells that are inhibited by interleukin 6. Nature 352:345-347, 1991.

23. Hartwell LH, Kastan MB: Cell cycle control and cancer. Science 266:1821-1828, 1994.

24. Yount GL, Haas-Kogan DA, Vidair CA, Haas M, Dewey WC, Israel MA: Cell cycle synchrony unmasks the influence of $\mathrm{p} 53$ function on radiosensitivity of human glioblastoma cells. Cancer Res 56:500-506, 1996.

25. Kastan MB, Onyekwere O, Sidransky D, Volgestein B, Craig RW: Participation of p53 protein in the cellular response to DNA damage. Cancer Res 51:6304-6311, 1991.

26. Kuerbitz SJ, Plunkett BS, Walsh WV, Kastan MB: Wild type p53 is a cell cycle check point determinant following irradiation. Proc Natl Acad Sci USA 89: 7491-7495, 1992.

27. Agarwal ML, Agarwal A, Taylor WR, Stark GR: p53 Controls both the $G_{2} / M$ and the $G_{1}$ cell cycle checkpoints and mediates reversible growth arrest in human fibroblasts. Proc Natl Acad Sci USA 92:8493-8497, 1995.

28. Cross SM, Sanchez CA, Morgan CA, Schimke MK, Ramel S, Idzerda RL, Raskind WH, Reid BJ: A p53dependent mouse spindle checkpoint. Science 267: 1353-1356, 1995.

29. Hockenbery DM, Zutter M, Hickey W, Nahm M, Korsmeyer SJ: BCL2 protein is topographically restricted in tissues characterized by apoptotic cell death. Proc Natl Acad Sci USA 88:6961-6965, 1991.

30. Fukunaga-Johnson N, Ryan JJ, Wicha M, Nunez G, Clark MF: Bcl-2 protects murine erythroleukemia cells from p53-dependent and -independent radiationinduced cell death. Carcinogenesis 16:1761-1767, 1995. 